Word count (article and references): 11,863

\title{
Recycling, recovering and preventing "food waste": competing solutions for food systems sustainability in the United States and France
}

\author{
Marie Mourad $^{a}$
}

\section{$\underline{\text { Abstract }}$}

In recent years, a wide range of organizations in developed countries have embarked on efforts to address the economic, environmental and social impacts of "food waste." Based on more than 120 interviews and complementary observations in the United States and France, this paper examines how recent mobilizations impact the way surplus food is actually managed with respect to sustainable production and consumption (SPC). The analysis of multiple stakeholders' interests and motives complements a growing literature on food waste prevention and management focused on technical evaluations of "solutions." Recent frameworks on food surplus and waste establish one hierarchy of preferable categories of solutions: first, prevention (reducing surplus at the source), then recovery (reusing for human consumption) and finally recycling (feeding animals, creating energy or compost). Fieldwork results show that actors with different interests in food commodity chains actually develop competing solutions, both within and between three hierarchies based on environmental, social and economic goals. In the long term, the solutions they promote may therefore not achieve "win-win-win" benefits for all actors and at all scales. Drawing on a distinction between "weak" and "strong" sustainability, this paper argues that "strong" prevention based on holistic changes in the food system is the most sustainable solution to food surplus and waste. It suggests that academics focus on strong food surplus prevention, but also that advocates encourage government and corporate actors to differentiate between weak and strong actions to diffuse strong sustainability across organizations and countries.

\section{$\underline{\text { Keywords }}$}

Food waste

Food surplus

Waste prevention

Sustainability

Recycling

Re-use

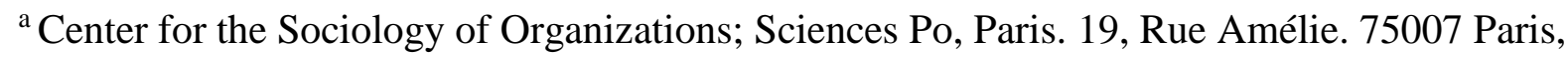
France.marie.mourad@sciencespo.fr 
Over the last few years, a wide range of organizations in developed countries have embarked on efforts to address the economic, environmental and social impacts of "food waste," estimated at a third of food production in North America and Europe (Gustavsson et al., 2011; see Schneider, 2013a for a review). International organizations and advocates argue that producing food that does not get eaten represents an unnecessary exploitation of land, water, and other resources, in addition to worsening food insecurity (Lundqvist et al., 2008; Stuart, 2009). Reports claim that food waste accounts for a share of global carbon emissions equivalent to a medium-sized country (FAO, 2013). National studies have explored the various causes of food losses and waste--stating that up to half happens at the consumer level in developed countries--and calculated its economic cost--amounting to more than 161 million USD a year in the United States (Buzby et al., 2014; MEDDE, 2012; WRAP, 2013). In this context, many private companies and community organizations have started initiatives to "recycle," "recover," and "prevent" what they characterize--in different ways--as "food waste." This article examines the extent to which recent mobilizations around food waste shift the management of surplus food towards sustainable production and consumption (SPC) in two developed countries, France and the United States.

In both countries, most organizations working to reduce food waste endorse a "food recovery hierarchy" that ranks the most appropriate responses to surplus food: prevention (reducing at the source; optimizing processes; adapting production to needs), recovery (redistributing food to people who need and/or want it), and finally recycling (feeding animals; using scraps for industrial production, energy, or compost) (EC, 1975; EC, 2008; US EPA, 2011). ${ }^{1}$ This paper shows how in practice the three approaches and the solutions they imply compete with one another in multiple hierarchies based on environmental, social and economic interests. The dominant visions of food waste and subsequent solutions generally focus on the management of existing surplus through recycling and recovery, overlooking long-term shifts toward sustainability. Moreover, both in France and the U.S., the most common initiatives towards prevention focus on increasing efficiency and question neither the power relationships and scale of food commodity chains nor the appropriate levels and patterns of consumption. Multi-stakeholder mobilization, which is three years older and more developed in France, has encouraged mostly marginal changes toward sustainability.

The central contribution of this paper to the growing literature on food waste is to highlight the limitations of each category of solutions and the tensions between them, drawing on data from more than 120 stakeholders in two countries. Further, it shows that analyses of prevention should distinguish between "weak" and "strong" actions with respect to sustainable production and consumption (Lorek and Fuchs, 2013; O'Rourke and Lollo, 2015). The article thus suggests that a switch from recycling, recovery and weak improvements to stronger prevention is necessary to achieve more "radical" changes (from Latin radix, the root) that address root causes of food waste (Lorek and Spangenberg, 2014; Tukker et al.,

\footnotetext{
${ }^{1}$ Wording may vary depending on institutions. In this article, "recovery" refers to food recovery (also called redistribution) and not energy recovery (part of or below "recycling" depending on the hierarchies).
} 
2008). This comparative analysis of the concrete case of food waste, revealing similar tensions in two national policy contexts, informs theoretical discussions on sustainable production and consumption in developed countries by highlighting inherent competition between weak and strong solutions. Significant implications can be drawn not only for researchers, but also advocates who have to further analyze and encourage government, nonprofit, and business actors to implement strong prevention actions.

The paper is structured as follows: Section 2 discusses the relevance of the question for the study of food waste and food system sustainability. Section 3 describes the data collection, which consisted primarily of 120 in-depth interviews. Section 4 analyzes the emergence of a food waste "movement" which combines actors with distinct environmental, social, and economic goals that promote distinctive, competing solutions to food surplus and waste. Section 5 discusses the potential of the food surplus and waste issue to lead to the sustainable production and consumption of food. Section 6 concludes on the implications of this study for food waste management and food system sustainability.

\section{$\underline{2 .}$ Relevance of the research and theoretical framework}

Complementing technological or quantitative assessment of impacts, this research explores challenges and opportunities that arise when actors across value chains, with differing objectives and motives, implement various hierarchies of actions around food waste.

\subsection{Exploring environmental, economic and social aspects of the "food waste hierarchy"} An increasing number of studies in waste management, industrial ecology and circular economy specifically address food waste through the concept of a "hierarchy," often referred to as the "3Rs"--reduce, re-use, recycle--of waste management. A European directive first put this hierarchy into law in 1975 (EC, 1975), while the U.S. Environmental Protection Agency endorsed a similar framework in guidance documents that specifically addressed food (US EPA, 2011).

Research has analyzed the implementation of this hierarchy for various types of waste (Hultman and Corvellec, 2012; Van Ewijk and Stegemann, 2015), including, more recently, food (Garcia-Garcia et al., 2015: Fig. 5 p. 70, Papargyropoulou et al., 2014). Scholars advocate for a holistic "food surplus and waste framework" based on the waste hierarchy to "tackle food surplus and waste throughout the global food supply chain" (Papargyropoulou et al., 2014). The hierarchy is a useful concept because it encompasses the diverse ways surplus food enters various circuits of distribution, whether as a commodity, a free product, or an organic resource that can be re-commoditized.

In the existing literature, a major focus has been the environmental impacts of food waste (Cuéllar and Webber, 2010; FAO, 2013; Hall et al., 2009; Kummu et al., 2012; Venkat, 2011) analyzed in particular through life-cycle assessments (Buratti et al., 2015; Eriksson et al., 2015; Lundie and Peters, 2005; Schenck and Huizenga, 2014; Williams and Wikström, 2011). As Papargyropoulou et al. (2014) acknowledge, "the waste hierarchy, as a framework, primarily focuses on delivering the best environmental option" (p.110), and is part of American and European environmental laws. Yet the concept of a hierarchy based only on environmental criteria is a "rough generalization" (Eriksson et al., 2015). For example, 
accounting for GHG emissions only, anaerobic digestion of food waste can have a better impact than using surplus for animal feed or for donations (which are even higher in the hierarchy), depending on the surplus products' characteristics such as water and energy content (ibid).

Thus, while food waste has been generally considered in terms of its environmental impacts, environmental, social, and economic values can compete in practice. It is therefore important to reinforce the study of economic and social implications of most solutions. Food waste solutions can be subject to economic and financial analyses such as the ones conducted for packaging waste recycling in France and Europe (Cabral et al., 2013; Da Cruz et al., 2014). Moreover, while food waste scholars increasingly exchange with the fields of public health or food poverty (Escajedo San-epifanio and De Renobales Scheifler, 2015, Neff et al., 2015a), studies assessing the potential of food redistribution (O'Donnell et al., 2015; Phillips et al., 2011; Reynolds et al., 2015; Schneider, 2013b) should be put into perspective with social and political criticisms of such systems (Midgley, 2013; Poppendieck, 1999).

Finally, all the categories of solutions along the hierarchy need to receive equal scientific attention. Most studies on food waste solutions have so far focused on what is actually the bottom of the hierarchy: recycling. Higher levels of the hierarchy are difficult to measure in terms of environmental impacts and the analysis of recovery is more uncertain than that of recycling (Eriksson et al., 2015). Among all the responses to food waste, prevention is the least tangible and directly measurable (Gentil et al., 2011; Laurent et al., 2014; Zorpas and Lasaridi, 2013). Studies on prevention thus generally focus on individual behavioral changes rather than systemic outcomes.

The contribution of this paper, with respect to the food waste hierarchy, is to put into perspective the environmental, social and economic dimensions of each set of solutions simultaneously, based on the point of view of different actors with competing motives.

\subsection{Encompassing a wide range of actors along the food chain}

Reducing food waste can be seen as a "social dilemma" or "public goods game" involving a wide range of actors, some of which are "cooperators" putting resources to reduce waste and others are "defectors." The qualitative research in this paper complements behavioral economics and computational sciences on these behaviors and co-evolutionary dynamics (Perc et al., 2013; Perc and Szolnoki, 2010). By analyzing the differing points of views and strategies of various actors in two national policy contexts, a sociological approach helps understand action mechanisms and organizational systems in place.

As surplus and waste exist all along commodity chains, an extensive analysis cannot be restricted to one stage within this system. In most developed countries, including France and the United States, studies have shown that food surplus and waste is most prevalent at the stage of consumption (Gustavsson et al., 2011). Yet, as experts point out, there is a lack of information about what is lost at the production and harvesting stages due to market fluctuations or aesthetic criteria for produce (Buzby et al., 2014; Kantor et al., 1997). Based on the available information, exploratory studies on specific sectors, such as produce in the U.S. (Berkenkamp and Nennich, 2015) and oil crops in France (Fine et al., 2015), confirm the existence of such waste at early stages of the value chain. Moreover, a large part of the consumer waste stream is generated by practices upstream, such as packaging, promotional 
offers, and restaurant portion sizes, as well as socially patterned consumption habits such as shopping frequency (Aschemann-Witzel et al., 2015; Evans, 2014, Hawkins, 2012; Le Borgne and Sirieix, 2013; Neff et al., 2015b). It is therefore important to look beyond the "producers/consumers" dichotomy to examine the chain in a holistic way, from growing food to the end of its life. Fundamental changes to solve a public goods dilemma require further attention to public policies and social institutions and cannot be restricted to consumer practices.

Such an approach also raises the issue of the appropriate scale of solutions. When recycling and recovery are promoted as ways to create closed loops or a circular economy, the number of intermediaries involved in the loop needs to be discussed. For example, should municipalities implement large-scale composting facilities or promote backyard composting? Answering such questions is all the more important because a larger scale, for its part, requires more formalized procedures to avoid potential contamination, which may generate more surplus and waste. The scale of a solution largely determines the governance of and actors involved in implementation.

Given the complexity of food-waste related processes at various scales, an international perspective offers insights on the mechanisms in place--as well as potential solutions--within the public, corporate and non-profit sectors. Recent analyses putting policies into perspective across European countries show that food waste enters many regulatory frameworks: beyond waste management, it is related to food safety regulation, food assistance policies, financial and tax frameworks (Vittuari et al., 2015). While dedicated regulation on food waste is on its way in France (Mourad, 2015; Samuel, 2015) and the U.S. (H.R.4184, 2015), it is necessary to identify and consider the whole spectrum of legal frameworks and policy actors in the food waste field.

\subsection{Analyzing potential changes toward "strong" sustainability}

The mobilization around food waste offers a valuable case to analyze the tension between fundamental and superficial changes in food system governance. We should analyze each solution and combination of solutions in relation with its potential to contribute to greater sustainability through "weak" or "strong" sustainable production and consumption (O'Rourke and Lollo, 2015). Even if recycling, recovery and "weak prevention" are generally focused on consumers and limited in comparison with "strong prevention," they have a potential for deeper changes and generating collective social, environmental and economic benefits if they constitute "incremental" steps toward stronger actions (Willis and Schor, 2012).

Interestingly, the emerging movement to address food waste transcends typical dichotomies in food politics, such as public vs. private or NGOs and social movements vs. companies (Holt Giménez and Shattuck, 2011; Schurman and Munro, 2010). "Institutional entrepreneurs" play an important role in diffusing ideas through organizations (DiMaggio, 1988). Similarly to environmental managers in the case of waste management (Rothenberg, 2007), young professionals and activists involved in food waste reduction could play an important role in pushing radical ideas towards sustainable production and consumption practices.

In the end, this research has relevant implications for governance and policies, by demonstrating the need for stronger prevention and the role that a wide range of actors in the 
political, corporate or non-profits realms can play in its diffusion. The example of food waste can then be of interest for the analysis of other commodity chains (Friedland, 1984; Gereffi et al., 2005; Gereffi and Korzeniewicz, 1994). While the study of production and consumption systems often overlooks the part which is not actually consumed, post-distribution and "waste" stages are actually key to the implementation of circular economy and sustainability. A better understanding of challenges and opportunities related to food waste solutions can help the relevant actors implement sustainable solutions in other sectors.

3. Data and methods: "diving" into the food waste movement

From 2013 to 2015, the author collected quantitative and qualitative data from a wide range of experts, policy makers, corporate representatives, workers, community leaders and activists working to address food waste in France and the United States. The two countries share similar levels of economic development and organization of food production, distribution and consumption. ${ }^{2}$ They have comparable levels of food surplus and waste (Gustavsson et al., 2011). On the other hand, the two nations differ in terms of consumption patterns, hungerrelief policies and waste management regulations, ${ }^{3}$ which allows for an examination of the impacts of these factors.

The author carried out 68 semi-structured primary interviews in France and 57 in the U.S., complemented by 19 and 29 secondary interviews (i.e. exploratory or informal discussions), respectively, along with more than 80 observations in both places at conferences, farms, processing plants, food banks, and composting facilities. Annex 1 summarizes data collected and Annex 2 presents interview details. In both countries, data collected through interviews and observations was complemented by analysis of scientific reports and documents on food waste--including confidential data from interviewees--and consistent follow-up on related news and social media.

After identifying the relevant actors for the prevention and management of food waste, the author grouped them in categories based on their role related to food waste (business and social innovation, multi-level policy, activism, corporate responsibility) and their activity in food commodity chains (production, wholesale, retail, catering, redistribution, etc.). Specific players such as representatives of consumers' organizations and financial markets dealing with agricultural commodities were included to enlarge the perspective. While they may simplify more complex realities such as overlapping fields and people and organizations with multiple involvements, categories were necessary for data analysis.

The author was generally granted the desired fieldwork access, with conditions of confidentiality particularly for industry facts and figures. In the U.S., part of the data was collected through regular volunteer work for one small non-profit organization and a major environmental organization, both working on food waste. In France, since 2012 the author has

\footnotetext{
2 The U.S. and France are both rich countries-the GDP per capita was 53,000 USD and 42,500 USD in 2013, respectively--with an industrialized and consolidated food system--the three main supermarket chains control more than $50 \%$ of the market in both countries.

3 For example, "food stamps" in the U.S. differ from French food assistance policies. Food expenditures accounted for $9.8 \%$ and $17 \%$, respectively, of disposable personal income in 2013. Waste management regulations and taxes are also different in each country.
} 
participated in multi-stakeholder working groups for the French National Pact Against Food Waste led by the Ministry of Agriculture and engaged in volunteer organizations and social movements.

Relevant categories were represented in comparable proportions for the two countries, with some variation to account for transnational differences: the public sector includes more activities in France than in the U.S., for instance, thus it is more represented in data collection in France (almost a quarter of interviews). More start-ups and NGOs focused on food waste were identified in the U.S. (with 23 interviewees as opposed to 15 in France), partly due to the size and innovation capacity of the country. Food assistance organizations are overrepresented in the U.S., reflecting the size of the charity sector and the author's opportunity to carry out in-depth investigations in two food banks (see Annex 1). Although most of the fieldwork was carried out in the Paris region in France and in the Bay Area, California, in the U.S., attention was given to obtain information from other French regions and American states, as well as a from Belgium, Italy and the United Kingdom for international initiatives. A fifth of French interviews were conducted in ten regions outside Paris and more than a third of the American interviews were conducted with organizations and individuals based outside California, in 13 different states.

The proportion of "secondary" interviews is higher in the U.S. (a third of the interviews, as opposed to around a fifth for France) mainly because the author had to carry out more exploratory research for the foreign fieldwork. 61 interviews were recorded while the rest was transcribed from notes afterwards. Basic statistical analyses and coding of recurrent facts, such as actors using certain framings or offering similar solutions, were performed using Excel spreadsheets. Based on the analysis of the interviews, the author identified how both individual and organizational actors understood surplus food and waste, their preferred sets of solutions, and how they related to a broader food waste movement. Observations at field sites allowed the author to compare discourse and practice. Given the qualitative nature of the data, this research aims at assessing potential challenges and opportunities--rather than direct effectiveness--of each category of solutions.

\section{$\underline{\text { 4. Results: competing visions of food surplus and waste solutions }}$}

Data analysis reveals multiple roots of the food waste movement and identifies a typology of actors with various visions of surplus food. Results further show the type of solutions they adopt (recycling, recovery, weak and strong prevention) and the tensions between solutions.

\subsection{A food waste "movement" with multiple roots}

As illustrated in Fig. 1, since 2008-2009, an increasing number of actors have been associating their activities with the expression "food waste" or "gaspillage alimentaire" in French, the latter of which is a more normative and usually pejorative label implying a suboptimal use of food. As one indicator, the appearance of the term in French media increased 40-fold between 2010 and 2014. ${ }^{4}$

\footnotetext{
${ }^{4}$ Appearance of "gaspillage alimentaire" on Europresse article database: 7 articles in 2007, 55 in 2010, 676 in 2012, and 2173 articles in 2014 (Searched: 3/9/2015).
} 
Following British author and activist Tristram Stuart's Waste: uncovering the global food scandal (2009), various groups around the world have organized events to raise awareness on the topic, generally through the free distribution of "rescued" food (Interviews $1,13,37,46,122,123)$. Food redistribution organizations have also started using the words "food waste" and communicating the environmental impacts of their donations (Interviews 81, 164). Industries in the U.S., including the Food and Marketing Institute, the Grocery Manufacturers Association and the National Restaurant Association formed a Food Waste Reduction Alliance (FWRA) in 2011. In France and the U.S., more than 30 start-ups and nonprofits were created since 2010 with the stated mission of "fighting food waste." 5

The rapid emergence of dedicated events and organizations was fostered by multistakeholders' initiatives in both countries. In France, a National Pact Against Food Waste, led by the Ministry of Agriculture since 2012, gathered multiple stakeholders committed to reducing food waste by $50 \%$ by 2025 by raising awareness, fostering partnerships, and improving regulations (MAAF, 2013). In the United States, hundreds of government, business and non-profit leaders from across the country gathered in conferences such as the first "Zero Food Waste Forum" (ZFWF) organized by environmental organizations in California in 2014, and the second ZFWF, partly led by the U.S. Zero Waste Business Council, in Texas in 2015 (Interview 127). These events emphasized industry best practices, local waste-related regulations, and awareness campaigns such as the Environmental Protection Agency's (EPA) "Food Recovery Challenge" or "Food: Too Good to Waste" campaign, which started in 2010.

In the meantime, the term "food waste" has appeared on national and local governments' political agendas. In April 2015, French policy makers released 36 proposals for a "national policy to fight food waste," some of which were under consideration by the French Parliament at the time of writing (Mourad, 2015). In September 2015, two years after France, the U.S. Department of Agriculture and the EPA announced a national goal to cut food waste in half by 2030 (Bloom, 2015).

Yet interviews and observations show that participants in the food waste movement come from diverse backgrounds and often have divergent interests in the food system. For many organizations that now use the framing of "food waste," food surplus was initially part of broader concerns and activities without being their main focus. The following streams of interests--not exhaustively--converged on food waste, albeit for different reasons:

- Anti-capitalism, food justice and food sovereignty: Social movements like "freegans" use food waste and "dumpster-diving" as a strategy to ostensibly live outside capitalism (Interviews 36, 42, 122). Other radical movements, such as Food Not Bombs, which has had chapters around the world since 1987, use surplus food to claim food as a right and offer "solidarity, not charity" by distributing free food in public spaces (Edwards and Mercer, 2007; Interview 122).

- Local and sustainable food systems: Slow Food, created in 1986 in Italy to advocate for "fair and good food," was the inspiration of some of the first events directly aimed

\footnotetext{
5 For example, the "Food Surplus Entrepreneur Network" counts 25 entities in France in 2015: http://fsenetwork.org/entrepreneurs/ (Accessed: 12/3/2015). Several entities identified during interviews in the two countries are not listed on online platforms.
} 
at cooking collectively with surplus produce to raise awareness about food waste, now called "Disco Soups" (Interviews 2, 13, 14; observation of Disco Soup events).

- Zero waste and environmental protection: "Zero waste" movements have focused on reducing all types of waste, not just that of food, since the 1980s. Public environmental agencies in the U.S. and France started focusing on food waste through diverting materials from landfills. Increasingly, environmental policies have emphasized the reduction of food waste, not only because organics compose a large part of the waste stream but also because producing food requires large quantities of land, water and other inputs (FAO, 2013; see, for example, interviews 46, 129, 133).

- Charity and social responsibility: Food banks started redistributing surplus, long before the notion of "food waste" became popular, as part of their charity work and to appeal to donors' sense of social responsibility (Interviews 81, 159, 168). 20 years ago, the U.S.'s Bill Emerson Good Samaritan Act of 1996 was passed to facilitate food donations and protect donors--generally, businesses benefiting from tax benefits-from liability.

- Agriculture and food security: The French Ministry of Agriculture and Food used to manage food surplus stocks generated by the Common Agricultural Policy through a quota system. Since the end of quotas in 2015, the Ministry has remained in charge of regulating production and may see redistribution of extra commodities through hunger-relief programs as an opportunity to limit surpluses (Interviews 21, 54). The U.S. Department of Agriculture started tracking data on food losses after World War II out of concerns for food security and availability. ${ }^{6}$ In 1997, the department organized its first conference on food recovery after realizing the double problem of hunger and waste (Interview 113).

- Industrial efficiency: Agri-food and food service companies have long managed losses and surplus to maximize economic efficiency. Several business representatives in the U.S. and France say that they want to reinforce existing efforts at a time of thin margins and economic downturn (Interviews 54, 55, 62, 65, 136, 144, 150).

In the two countries, despite these divergent activities and interests, most groups have converged on a similar "framing" (Snow and Benford, 1992) of food waste as an environmental, social and economic problem. Similar numbers and statements like "America throws away $40 \%$ of its food" circulate through institutional campaigns, grassroots organizations' websites, and expert reports (Gunders, 2012). The simultaneous presentation of environmental, economic, and social dimensions supports the construction of food waste as a public issue, especially in comparison with other types of waste. In France, a government representative explains that policies related to food waste gained more attention when they became part of the Food Administration, as opposed to other types of waste that were less "sexy"7 (Interview 19). Indeed, environmental activists mention their fear that current discussions on food waste may take away from discussing waste and over-consumption more generally (Interview 39).

\footnotetext{
${ }^{6}$ Loss-Adjusted Food Availability Documentation: http://www.ers.usda.gov/data-products/foodavailability-(per-capita)-data-system/loss-adjusted-food-availability-documentation.aspx (Accessed: 5/12/2015)

${ }^{7}$ All translations from French by the author.
} 


\subsection{Actors and organizations' differing visions of food surplus and waste}

Actors and organizations relevant to the prevention and management of food waste have different interests and places in food commodity chains, which allowed the author to place them in eight categories across the two countries (see Annex 1).

Despite efforts to build common measurements (HLPE, 2014, pp. 21-28; WRI, 2014), actors and organizations from distinct categories have very different definitions of "food waste" and adequate "solutions." The English word "waste" can relate either to something that has been "wasted"--like "gaspillage" in French--or something that was not necessarily usable in the first place, like "scraps" or "trash." In both languages, the threshold between a "good," "wise" use of resources and a "wasteful" one is variable. For example, the General Secretary of the French Federation of Wholesale Markets includes an incinerator project-supplying energy to a low-income neighborhood from food scraps--in her organization's "fighting food waste" policy, even though advocates of food recovery considered burning food still "waste" (Interview 68). A book author and advocate against climate change in the U.S. goes further and claims that converting grains into animal protein is a "waste" of resources (Interview 129).

As these examples illustrate, various public and private entities have distinctive visions of surplus food. They subsequently create hierarchies of what "solutions" they prefer for implementation. Behind the overarching prioritization of prevention, recovery and recycling, three environmental, economic, and social hierarchies of actions can be identified. They rank specific solutions based on the respective goals of protecting the environment, generating exchange and profit, and feeding people. As illustrated in Fig. 2, for each hierarchy, some categories of solutions are more likely to be implemented than others: for instance, actors and organizations focused on pollution and environmental impacts tend to promote recycling, businesses looking for economic benefits encourage the optimization of processes and sales, and non-profit entities with social goals dedicate themselves to food recovery and redistribution.

\section{[Insert Fig. 2 about here]}

Generally, actors consider food as "wasted" if it is exchanged in a way they consider sub-optimal within a given hierarchy. For example, from the economic perspective expressed by many corporate representatives, food is wasted if it is donated for free instead of being sold (Interviews 55, 61, 62, 140, 147, 150). From an environmental perspective, food is wasted if it goes to feed composting worms instead of feeding other animals (one step higher in the environmental hierarchy), as one farmer and several environmentalists put it (Interviews 27, 115, 118, 139). Measurement units help rank the actions in each hierarchy: environmental impacts are measured in tons of waste, $\mathrm{CO} 2$ emissions, or impacts on soil and water; social impacts by numbers of meals or calories; and economic impacts as savings or profits. Individuals and organizations are negotiating specific thresholds for moving food from one circuit to another, such as expiration dates that distinguish between saleable food, potentially donated food, and (supposedly) non-edible food to be thrown away.

Yet, as surplus food is a material and perishable good, the ways to manage it are limited and not always compatible. For example, redistribution can compete with composting: food can be offered to a charity to be donated and then be composted, but not the other way 
around. Actors at national, regional and local scales in both countries show that funding such as investments and grants, informational resources such as communication campaigns or media coverage, and human resources are finite, so not all actions can be effectively promoted at the same time (Interviews 18, 20, 21, 112, 117, 118).

In this context, the author analyzes what hierarchies and solutions are the most dominant, based on which appear the most in public reports and discussions, in the media and during interviews, as well as which are the most encouraged or funded by policies and turn into concrete projects. People and organizations do not generally refer to only one solution or even one set of solutions, but analyzing the most common ones helps understand how surplus food is actually being managed. The following sections on recycling (4.3), recovery (4.4), and "weak" (4.5) and "strong" (4.6) prevention present further fieldwork results on 1) the meaning and implementation of each category of solutions; 2) the opportunities for and competition between environmental, economic, and social interests in the respective hierarchies; 3) the broader challenges each raise. Fig. 3 summarizes the potential benefits, barriers and limitations of each category of solutions as well as their key proponents.

\section{[Insert Fig. 3 about here]}

\subsection{Recycling: using "food scraps" as resources}

Recycling entails using "food scraps" or "organic resources" or "materials" " that cannot be consumed by humans. The food waste hierarchy ranks the most environmentally preferable uses of scraps as animal feed, industrial uses like chemicals or cosmetics, energy production through anaerobic digestion, and lastly, composting. Some innovations focus on feeding animals with food scraps, such as the "Pig Idea" campaign that was launched in 2013 (Interview 37). An increasing number of companies are also investing in infrastructures and technologies for "waste-to-energy" processes. For example, a project endorsed by the Innovation Center for U.S. Dairy aims to put 1,300 methane digesters on dairy farms by 2020 (Interview 137). French governmental subsidies support similar investments (Interview 19). In the meantime, municipalities like San Jose in California are increasingly processing municipal or commercial waste through centralized anaerobic digesters.

Many regulations and infrastructures aim to increase composting: in 2014, 198 U.S. municipalities had begun curbside collection of food scraps (Yepsen, 2015). A city official in California explains that a mandate on composting is the best way to make it financially sustainable and generalized: "When they started having waste collection in American cities in the $20^{\text {th }}$ century, people volunteered but it needed to be mandatory, for health and safety. Composting is 'health and safety' for the global community, it's the same" (Interview 119).

The comparison of the two countries and wide variations between U.S. states demonstrate the impact of financial taxes along with regulations: the higher cost of landfilling in France and in California vs. other U.S. states, for instance, means a higher "opportunity benefit" for diverting from landfill, making recycling more profitable (see Da Cruz et al., 2014, for an economic analysis on packaging waste). Economic incentives for recycling also depend on end-markets for biofuels or compost in agricultural areas, which vary widely across place and time (Interviews 87, 169, 170).

\footnotetext{
${ }^{8}$ Words in quotes are based on the lexical analysis of interviews in English or translated from French.
} 
In the end, recycling may be at the bottom of the food recovery hierarchy, but it is often promoted as the first solution by companies and municipalities, following the example of Californian cities that are often seen as leaders, including in France. One advantage of recycling--especially compared to prevention--is its directly measurable results: waste kept out of landfills. Despite the uncertainties of a new market and new technologies, recycling is seen as an opportunity to create both environmental and economic value. Even when capitalintensive projects are not profitable in the short term, they aim at complying with future regulation and providing long-term economic gains

Yet the different systems that public and private entities develop are not always compatible. One sustainability manager at a retail store explained they chose composting over anaerobic digestion because "I have this very simple approach: take food waste and compost it and grow more food! It's a personal philosophy" (Interview 148). A city official in California criticized a program that would centralize and mix food waste with wastewater materials to produce energy because the mixed digestate (the remaining material that was not only organic) would have to go to the landfill and therefore not match "zero waste" goals (Interview 119). Tensions between recycling methods are also arising in France where the waste management sector has become more and more privatized (Interviews 39, 41, 87).

At the same time, recycling is happening at an increasing scale through the commoditization of what was formerly "waste," notably in California. An owner of a family farm illustrates this phenomenon: "I used to go to a big bakery and now they donate everything to a big guy [one company] ... they would give bread to 20 people [20 different farmers]. Also I would get oil from restaurants...now they sell to companies that make biofuels...it has become a commodity" (Interview 139). Beyond tensions and competition around the commodification of waste, a key challenge associated with recycling is the risk of distracting from prevention and recovery efforts higher up in the food waste hierarchy. In San Francisco, a communication campaign for composting in 2014 depicted pizza leftovers in a cardboard with the caption "California Gold." The poster implied that recycling leftovers--not prevention--was an appropriate way to re-value food surpluses.

\subsection{Recovery: a new market opportunity for food surplus}

Food recovery involves accessing "extra," "excess," or "wholesome food"--rarely called "waste"--at production, distribution, and consumption in order to bring it to people who need or want it. Food recovery can involve gleaning unharvested produce on farms and at markets, re-processing food (for example, making jam with blemished products), or rapidly matching the supply of available extra food to the demands of food banks and charities.

Recovery is one of the most frequently promoted solutions to food waste in both countries. People working for local governments, food corporations, hunger-relief organizations, or recently created social enterprises all use a similar rhetoric: entrepreneurship, innovative technologies, and better logistics can "solve the problem of food waste" by connecting surplus food with "hungry" people, in a social, economic, and environmental "win-win-win." Recovery makes sense to many producers and businesses that see surplus food as "necessary" or as a "normal part of business" because of seasonality, variability of prices, and unpredictability of demand. Similarly, a redistribution agency insists that caterers "have to waste, especially when they do not know how many people they will be 
serving... They always produce 10\% more, it's not an exact science... if there were a place for all of the food left over everyday by the normal business as it's run, then no one in America would be hungry" (Interview 90).

For corporations, recovery is a way to benefit from tax incentives for donations and save on disposal costs while improving their public image. In France, companies' tax reductions (subtracted from taxes) account for $60 \%$ of their in-kind donations' stock value, within the limit of $0.5 \%$ of sales (Art. 238bis CGI, 2014). Although the complexity of tax codes makes direct comparison difficult, France's incentives appear to be among the strongest in Europe if not the world (Vittuari et al., 2015). In the U.S., qualified business taxpayers receive tax deductions (calculated before taxes) derived from the cost to produce the donated food and its full fair market value and limited to $15 \%$ of the taxpayer's income (H.R.4719, 2014). Additional tax incentives exist in some states: for example, the Colorado Charitable Crop Donation Act, signed in 2014, offers a $25 \%$ tax credit to local producers for the wholesale value of the food that they donate to food banks.

While historically food recovery was mainly carried out by non-profit organizations, a few start-ups now see it as a potential profit-making opportunity. For example, a mobile application created in Chicago in 2014, that connects American restaurants and caterers with local charities, charges businesses a fee proportional to their tax deductions to pick-up and donate their extra food (Interview 93). In that case, financial incentives are key to transforming environmental or social benefits into economic value. As a person responsible for food waste prevention at the West Coast office of the EPA phrases it, "we just need to align economic incentives with the food recovery hierarchy!" (Interview 115).

Yet, while estimates show that less than $10 \%$ of surplus food is currently redistributed in the U.S. (FWRA, 2014), few actors ask what would happen if more food were redistributed. One of the main challenges of food recovery is that food donations are not necessarily adapted to the needs of hunger-relief organizations and their "clients," especially in terms of nutrition. Many food banks already have too much of certain foods such as bread and pastries. One manager of a food bank in Arizona explained that a large share of the donated food is given to bears, not humans (Interview 159). In France, the founder of a food assistance organization denounced the fact that hunger-relief policies often do not question the quality of the food and dignity of access: "they [policy makers] count in kilograms per poor person!" (Interview 82). In that system, some companies are encouraged to donate (and food banks are encouraged to distribute) "heavy" foods that are not necessarily nutritious, like soda (Interviews 83, 161, 166). Activists use the label "charity washing"--based on the notion of "green washing"--to denounce fake charitable actions that dump unneeded products (Interviews 81, 130).

In the meantime, food recovery is increasingly becoming institutionalized. Donations are associated with formalized procedures to protect from liability, ensure compliance with safety rules, and calculate tax incentives. The food bank network Feeding America is developing national agreements with chain stores' headquarters to obtain regular in-kind donations and financial support for large infrastructures (Interview 162). In both national contexts, this formalization conflicts with grassroots organizations that distribute food from restaurants and caterers to homeless shelters. Many small-scale agencies do not have 
the local level might be disrupted, along with more informal practices like giving food to stores employees at the end of the day or showing clemency to "gleaners" and "dumpster divers" who salvage food left on the ground or in supermarkets' dumpsters. ${ }^{9}$

\section{5. "Weak" prevention: food waste as a dysfunction}

Prevention is ahead of recovery in the food surplus and waste hierarchy, but often last in practice. In order to avoid "losses," "breakage," "dysfunction," "shrink," "mistakes," or "errors" at each stage of the food chain, prevention aims at optimizing the level of "desired food surplus" necessary to offset risks (Papargyropoulou et al., 2014). Optimizing production quantities also relies on raising "awareness" among consumers, often seen as responsible for developed countries' waste (Interviews 45, 126). Campaigns focus on the consequences of waste and its drivers at an individual level, such as poor planning, storing and cooking practices or the use of expiration dates.

Businesses and environmental organizations promote their own optimization practices as an environmental and economic "win-win" that reduces the "cost of doing business" and the "externalities" of waste. Professionals in the retail, processing or catering sectors increasingly share "toolkits" and "best practices," carry on waste tracking audits, or even hire technical assistance to improve processes and train employees (Interviews 55, 66, 76, 136, 144, 152, 153). A start-up created in 2007 to improve waste measurement and management in the American food service sector was one of the first to propose a service to optimize "food waste" based on weighing and tracking (Interview 89). Many social entrepreneurs in France and the U.S. promote optimization "solutions," such as smart-phone applications and technologies that help sell products close to their expiration dates at a discount price in order to increase sales and reduce waste (Interviews 9, 94).

As defined here, "weak" prevention relies on the belief that improved processes and technologies--without a fundamental change in business models--are enough to significantly prevent and almost eradicate waste. A report produced with French industry experts promotes "smart" packaging and technological innovation as a significant way to prevent waste, with the support of the Ministries of Industry and Agriculture (PIPAME, 2014). One large-scale produce farmer in Southern California argues that "in about 20-30 years if we are smart, use new technology, we won't have the word 'waste' anymore" (Interview 138). Technologyoriented discourses seem more prevalent in the U.S., especially when it comes to farming techniques (including GMOs) that have not been accepted in Europe so far.

Prevention based on optimization is nonetheless weak for several reasons. First, prevention often relies on companies' voluntary commitment and "best practices," both of which do not push beyond economic profitability. Second, prevention is often predicated on the assumption that it will not lead to major transformation in food markets. There is generally no assessment of what would happen if consumers stopped buying the food that is currently wasted, up to $40 \%$ of total purchases. As the director of sustainability at a large French retail chain confesses, "when jam sales decrease because people make more jam at home with blemished fruits, chicken will have teeth [French equivalent of "when pigs fly"]!"

${ }^{9}$ Fieldwork observations revealed that many store managers allowed such practices, in both countries, despite corporate guidelines that sometimes recommend to "bleach" food in order to make it inedible. 
(Interview 62). In fact, most interviewees in the retail sector do not expect consumer waste to decrease enough to reduce sales.

Currently, the changes that are promoted to prevent waste are generally marginal ones and industry leaders consider waste reduction as a "pre-competitive" issue on which companies, through the food waste reduction "alliance" or "pact," can work together to comply with similar standards, maintain certain market characteristics, and adapt to or preempt government regulations (see, for example, interviews 53, 64, 136, 137, 156). As one leader in the Food Waste Reduction Alliance mentions, "When the government comes up with regulations, it always screws up everything... We are in the best position in the private sector to manage our own impact...[rather] than having the government telling us what to do" (Interview 150). The discussions on expiration dates, both in France and in the US, are emblematic of an attempt to optimize practices and processes--raising awareness about dates and homogenizing rules--without changing the overarching system of date setting--including the persistence of dates on non-perishable products like salt or flour--that still accounts for a significant percentage of waste (Leib and Gunders, 2013; Lyndhurst, 2011).

\section{6. "Strong" prevention: reducing waste through structural changes} Only "strong" prevention would question what a "desired surplus" (Papargyropoulou et al., 2014, p.112) is and, beyond optimizing processes, limit the production and consumption of unneeded food. Several activists and advocates point out that the most common definitions of waste distract from its biggest drivers in developed countries: intensive and capitalistic production of food. Based on the realization that more than 3,500Kcal per capita are produced daily in the U.S. and France, ${ }^{10}$ while a normal human should consume only around 2,000$2,500 \mathrm{Kcal}$, they call for actions at the top of all environmental, economic, and social hierarchies to change the core organizing principles of production and consumption.

Advocates of strong prevention challenge "productivism," "over-industrialization," and "homogenization" of food production, along with the permanent availability of a wide range of foods through complex commodity chains (Interviews 13, 38, 42, 91, 110, 122). They question food safety criteria that entail throwing away large quantities of food or the loss of nutritional quality and freshness (Interviews 21, 25, 63, 75, 118, 138, 153). Many interviewees claim that strong prevention would require, among other things, more seasonality and variability, with greater proximity to the land or "nature," and sharing more food through stronger social links (Interviews 3, 7, 11, 12, 104, 105). Several farmers and cooks mention the necessity for people to be "closer to the food" (with fewer intermediaries) through less standardized exchanges (Interviews 4, 51, 59, 79, 139, 142). Another aspect may be the de-commodification of certain products, related to the idea of food sovereignty and a "right to food."

Although focusing on individual consumers is criticized as a "weak" approach, "strong" prevention of food surplus would still imply important changes in consumption patterns, including less choice and availability, more time spent around food, potentially more risk, reduced animal products consumption, and reduced overall consumption. Some advocates even consider reducing consumers' convenience and refer to "traditions" from

\footnotetext{
${ }^{10}$ Sources: Food and Agriculture Organization (FAO) and U.S. Department of Agriculture.
} 
many cultures and religions that required thriftiness and efforts (see, for example, interviews

$$
11,27,45,88,94) \text {. }
$$

An interesting case of potentially strong prevention, entailing possibly systemic and comprehensive changes from production to consumption, is the recent initiative around "ugly fruit and vegetables" that generally do not reach markets because of their shape or color. After the French retail store Intermarché led a very successful marketing campaign to sell carrots that are "ugly" but "good in the inside" at a discounted price, many companies in Europe and the U.S. started exploring similar initiatives (Interview 69). Innovative start-up projects in the U.S. have begun delivering boxes of "cosmetically challenged" produce (Interviews 106, 107).

Changing esthetic criteria may "strongly" modify long-standing social and cultural expectations on what a good fruit or vegetable is, along with the way produce traders and merchants do business along commodity chains. By reducing unharvested crops, farmers could be paid for a larger part of their production and at the same time make fresh produce more affordable to low-income communities (with additional support of public policies focused on health and nutrition), in a true "win-win" fashion. It may change food production and consumption systems by valuing labor, taste, nutrition and resources more, and branding and standardization less.

Yet the scalability, effectiveness and long-term impacts of such programs are still unclear. Up to the time of writing, the French marketing campaign spread "ugly" to other stores, but the impact on sales and prices was unknown (Interview 69). Farmers expressed concerns about an overall decrease in the prices for their produce (including the non-ugly ones) while retailers would maintain relatively high end-of-market prices and benefit from higher margins (Interview 58). In a weak scenario, changing aesthetic standards may not question who sets the standards, nor the power of supermarkets to reject certain food through the way supplier-retailer contracts are set up.

In the end, strong prevention is the least promoted solution and only appears in marginal social movements or in individual conversations as a non-official discourse. Only a few environmental organizations have publicly promoted individual practices that could significantly reduce resource waste if they were collectively embraced, such as eating less meat or imported fruit (Interviews 38, 46, 121, 135). A network of young professionals with engineering or business schools degrees and specialized trainings in environmental studies are also spreading "strong" ideas across retailing companies, government agencies for agriculture or the environment, non-profit environmental organizations, and consulting companies. Playing the role of "institutional entrepreneurs" across organizations and countries, some describe themselves as "internal lobbyists" (Interviews 66, 147). While a woman working at one of the main French grocery stores explains that she chose to change things in the long run "from the inside" by talking about her own ethical consumption and sustainability in her work, she adds, "it may be less naïve [than more radical engagements] ... or more naïve" (Interview 68).

Indeed, most interviewees do not consider strong prevention a "real" solution, and, despite depicting some changes as desirable, they refer to them as "idealistic" and "utopian." For example, safety criteria based on senses, not labels, and relationships based on trust, not formal agreements, do not seem to be possible in the current organization of production, 
distribution and consumption. When they individually mention "overproduction," people do not challenge it or describe it as "part of the system." A member of the Ministry of Agriculture leading discussions for the French pact against food waste confesses: "If I talked about this, they [producers and unions representatives] would just stand up from their chairs and leave" (Interview 21). Food waste reduction has not been directly included in the U.S. Farm Bill or the European Common Agricultural Policy (CAP), although the latter has taken steps towards less productivist agriculture (Interviews 29, 151). Until now, despite their significant growing rates, alternative forms of food production and consumption remain marginal (less than $5 \%$ of the market) ${ }^{11}$ in both countries.

11

12

\section{Discussion: an impact on the food system?}

Previous research has suggested that significantly and sustainably reducing surplus food in France and the United States calls for holistic and systemic changes in the production, distribution and consumption of food. Yet, results show that the most promoted solutions and dominant approaches to "food waste" often focus more narrowly on the management of existing surplus. Interestingly, despite differences in the way the French and American food systems are organized and embedded in distinct cultures and political context, key policies and initiatives embraced on "food waste" remain similar. Fig 4 shows key achievements on the food waste field in terms of policies and corporate initiatives, most of which focus on the bottom stages of the hierarchy. Future developments in both places will allow researchers to assess to what extent proactive public policies and regulations are effective.

\section{[Insert Fig. 4 about here]}

Until now, recycling, recovery and weak prevention have encouraged, first, the optimization of large-scale and standardized (over)production systems that require large surpluses and, second, the re-use of inevitable surplus to feed inevitably hungry people before recycling the remainder. Strong prevention still seems incompatible with current economic paradigms because its social and environmental values do not easily translate in economic values, as opposed to other categories of solutions that can bring about direct economic benefits. Even solutions that join different economic, social, and environmental interests, supported by entrepreneurship and innovation, generally do not challenge underlying power relationships that define how decisions are made or who controls the profit margins on food markets. In particular, "food waste" concerns have yet to enter overarching agricultural and industrial policies.

With rising attention to food waste, many small-scale systems--dumpster-diving, donations from a store manager to a local charity or a local farmer, or gleaning--end up being disrupted in favor of supposedly more efficient large-scale and formalized forms of exchange. At each level, tensions arise about the scale of reducing, re-using, and recycling: backyard composting vs. industrial composting, local organizations vs. food bank networks, etc. The scale goes along with certain standards for food safety and administrative procedures to ensure trust despite the lack of direct inter-personal relationships. While studies about food

\footnotetext{
${ }^{11}$ Sources: French agency for waste prevention (ADEME) and U.S. Department of Agriculture.
} 
waste have already established the importance of a hierarchy of the three "Rs" (Garcia-Garcia et al., 2015: Fig. 5 p. 70, Papargyropoulou et al., 2014), this research shows we also need to take into account the scale at which each stage in the hierarchy is best implemented.

Dominant solutions to food waste push for marginal changes and individualized approaches that may be a diversion from more radical actions. For instance, corporations may use food waste as a way to improve their Corporate Social Responsibility and environmental images--generally managed by separate departments or delegated to foundations in large companies--while maintaining day-to-day practices that can include pressuring charities to accept food that is not adequate and to subsequently bear the cost of disposing of it.

Yet, addressing food waste nonetheless holds the potential for incremental change towards more radical shifts in the long run, with individual practices leading to more political action, and corporate initiatives leading to broader structural changes. There is indeed a potential for a "switch" from weak to strong sustainability through a network of individuals or "institutional entrepreneurs," across a wide range of organizations at different scales, who take action to change the system "from within" and spread more radical values. Despite its limitations, we can observe a "movement" toward the actual reduction of food waste in both countries. Regardless of companies' motives for doing so, it is relevant that they do feel significant pressure to address environmental and social concerns, in this case by taking action to optimize, redistribute, or recycle food surplus.

Relatively long-term change in cultural and social expectations, encouraged by education, may alter business practices and regulation. France is now considering a law making donations of supermarkets' surplus food mandatory, adding a coercive dimension to existing incentives. Regulations may be the ultimate point of leverage in addressing food waste as a public goods dilemma. Once individual and business practices evolve, regulations can set higher standards and transform markets towards sustainability, for instance with tax incentives to encourage donations. Public policies might be able to align financial goals and productive logics with sustainability and social goals. For example, the European Directive on a "circular economy" or recent transformations of the CAP, with the end of production quotas in 2015, show an evolution toward the transformation of production and consumption systems.

The cases of the French and American food systems suggest some prospects for incremental change leading to long-term transformations. The U.S. seems behind in terms of corporate sustainable initiatives, with low incentives for waste reduction (low landfill costs) and the institutionalization of "charity" that maintain a permanent need for surplus. Across the Atlantic, French officials are more apt to mention concepts like a "circular" or "sharing economy" (not yet "de-growth" or "radical" changes), conversations that seem almost taboo in the U.S. A majority of interviewees see regulation and policy approaches as disfavored in the U.S. compared to innovation and entrepreneurship, while French public entities try to implement proactive regulations. Despite potential resistance from the food sector, new guidelines for French public policies offer an optimistic vision of potential changes toward stronger prevention and sustainability in the food system.

\section{Conclusion}


The generalization of current patterns of production and consumption, especially to developing countries with large populations (Myers and Kent, 2003), will not be sustainable without a radical change in the way resources are used. Given that food surplus and waste are increasingly identified as an example of sub-optimal resource-use in developed countries (see for example Thyberg and Tonjes, 2016), research needs to be pursued to further understand the challenges and opportunities raised by potentially competing solutions to this problem with regards to sustainable production and consumption.

This research found that, in terms of social, environmental, and economic values, various solutions appear to constitute competing categories and hierarchies of solutions, in contrast to the single hierarchy usually mentioned in the literature and endorsed by most actors. Overall, beyond recycling, reusing, or weak prevention, strong prevention requires rethinking the overall governance of the food system and its underlying power relationships between producers, manufacturers, retailers, food banks, NGOs, and other actors. In particular in a context of rapid population growth, only structural transformations of both food and economic systems would ensure universal access to nutritious food in adequate--and not excessive--quantities.

This paper shows that "strong prevention" has been the least promoted and most marginal solution so far, although it is the best opportunity from a long-term sustainable production and consumption perspective. While weak technical and logistical solutions are linked to social, economic, and environmental issues that may jeopardize their sustainability in the long run, this paper argues that researchers will benefit from focusing on how to achieve strong prevention. Advocates are also encouraged to push corporate and government actors to move toward strong prevention. The case of food waste could then be extended to other commodity chains that require similar changes in production and consumption patterns.

France and the United States were used as empirical cases because they are two developed countries with similar amounts of food waste despite contrasting food cultures and food policies. Various mechanisms observed in France and the U.S. may be shared by other developed countries, notably the recent appearance of food waste on the political agenda and the concentration of efforts on recycling, the bottom of the hierarchy (Eriksson et al., 2015). More generally, the challenges to strong sustainability--not only in the field of food commodity chains--are shared by most industrialized, capitalist economies. Yet, some policies and initiatives remain specific to each national context, such as the strength of tax incentives for company donations in France, which demonstrates the impacts of local actors' and governments' proactivity.

This paper's empirical results were obtained through in-depth investigation among a wide panel of policy makers, professionals, experts and activists in dozens of states and regions in the U.S. and France. The sample nonetheless remains qualitative: the goal was to include representatives of each relevant category of actors rather than to ensure an exact representativeness of each. The data is limited to the information that actors are willing to give. Other studies may complement this analysis by quantifying the competing impacts of different categories of solutions.

Another potential limitation of this study lies in the difficulty of comparing a variety of administrative levels in the two countries (European vs. federal, national vs. state and local). The author also faced the challenge of keeping up with recent developments. For 
2 example, regulatory changes were taking place in France at the time of writing, where a "food 3 waste bill" was unanimously approved at the National Assembly on December 9, 2015

4 (Samuel, 2015). On December 7, Rep. Chellie Pingree (Democrat, Maine) formally

5 introduced federal legislation to reduce food waste in the U.S (H.R.4184, 2015).

More research must examine the most appropriate scale at which hierarchies of

7 solutions should be implemented. While economies of scale may lead to more efficiency,

8 increasing the length of commodity chains requires more administrative procedures and more

9 safety measures that generate more surplus and waste. Additionally, despite a growing

10 number of studies on food waste, actors in the field point out that very few of them have

11 provided an in-depth analysis of the macro-socioeconomic implications of different solutions

12 and on the impacts of applying the "hierarchy" at one level or another. Analyzing the

13 implementation and efficiency of various policies and initiatives is particularly necessary, for

14 example determining the impact of "mandatory composting" regulations (beyond the analysis

15 of compost efficiency itself) as well as future "mandatory donations" laws. Strong prevention

16 actions such as the seasonal provisioning of imperfect produce deserve even closer attention.

17 By seeing existing real opportunities, advocates and policy makers will hopefully seize them

18 and, beyond marginal adaptations, will work on strong changes toward sustainable production

19 and consumption.

\section{Acknowledgements}

22 This work was supported by grants from Région Ile-de-France (not involved in the design, implementation and publication of this research). The author would like to thank Sophie

24 Dubuisson, Dara O'Rourke and Alex Barnard for their support in writing and editing the manuscript. The author is sincerely grateful to four anonymous reviewers and the editors for their help in improving the manuscript. 


\section{$\underline{\text { References }}$}

Article 238bis, 2014. General Tax Code (Code Général des Impôts). Available at: http://www.legifrance.gouv.fr/affichCodeArticle.do?idArticle=LEGIARTI000021658 127\&cidTexte=LEGITEXT000006069577 (Accessed: 12/18/2015)

Aschemann-Witzel, J., de Hooge, I., Amani, P., Bech-Larsen, T., Oostindjer, M., 2015. Consumer-Related Food Waste: Causes and Potential for Action. Sustainability 7 (6), 6457-6477. doi:10.3390/su7066457

Berkenkamp, J., Nennich, T., 2015. Beyond Beauty - The Opportunities and Challenges of Cosmetically Imperfect Produce (Report No. 1: Survey Results from Minnesota Produce Growers). Tomorrow's Table and University of Minnesota, Minneapolis, MN.

Bloom, J., 2015. Something To Shoot For: US Sets Food Waste Reduction Goal. Wasted Food. Available at: http://www.wastedfood.com/2015/09/16/something-to-shoot-forus-sets-food-waste-reduction-goal/ (Accessed: 12/18/2015)

Buratti, C., Barbanera, M., Testarmata, F., Fantozzi, F., 2015. Life Cycle Assessment of organic waste management strategies: an Italian case study. J. Clean. Prod. 89, 125136. doi:10.1016/j.jclepro.2014.11.012

Buzby, J., Wells, H., Hyman, J., 2014. The Estimated Amount, Value, and Calories of Postharvest Food Losses at the Retail and Consumer Levels in the United States (Economic Information Bulletin No. 121). U.S. Department of Agriculture, Washington, DC.

Cabral, M., Ferreira, S., Simões, P., Ferrera da Cruz, N., Marques, R.C., 2013. Financial Flows in the Recycling of Packaging Waste: The Case of France. Pol. J. Environ. Stud. 22 (6), 1637-1647. ISSN: 1230-1485.

Cuéllar, A.D., Webber, M.E., 2010. Wasted Food, Wasted Energy: The Embedded Energy in Food Waste in the United States. Environ. Sci. Technol. 44 (16), 6464-6469. doi:10.1021/es100310d

Da Cruz, N.F., Ferreira, S., Cabral, M., Simões, P., Marques, R.C., 2014. Packaging waste recycling in Europe: Is the industry paying for it? Waste Manag. 34 (2), 298-308. doi:10.1016/j.wasman.2013.10.035.

DiMaggio, P.J., 1988. Interest and agency in institutional theory, in: Zucker, L.G. (Ed.), Institutional Patterns and Organizations. Ballinger, Cambridge, MA, pp. 3-22.

Edwards, F., Mercer, D., 2007. Gleaning from Gluttony: An Australian Youth Subculture Confronts the Ethics of Waste. Aust. Geogr. 38, 279-296. doi:10.1080/00049180701639174

Eriksson, M., Strid, I., Hansson, P.-A., 2015. Carbon footprint of food waste management options in the waste hierarchy - a Swedish case study. J.Clean. Prod. 93, 115-125. doi:10.1016/j.jclepro.2015.01.026

Escajedo San-epifanio, L., De Renobales Scheifler, M. (Eds.), 2015. Envisioning a Future Without Food Waste and Food Poverty: Societal Challenges. Wageningen Academic Publishers, Wageningen.

EC, 1975. Council Directive 75/442/EEC of 15 July 1975 on Waste. The Council of the European Communities, Official Journal L 194, Brussels. 
EC, 2008. Directive 2008/98/EC of the European Parliament and of the Council of 19 November 2008 on Waste (Waste Framework Directive). Official Journal of the European Union, Strasbourg.

Evans, D., 2014. Food Waste: Home Consumption, Material Culture and Everyday Life. Bloomsbury Academic, London.

FAO, 2013. Food Wastage Footprint: Impacts on Natural Resources. United Nations Food and Agricultural Organization. Rome.

Fine, F., Lucas, J.-L., Chardigny, J.-M., Redlingshöfer, B., Renard, M., 2015. Food losses and waste in the French oilcrops sector. OCL 22 (3), A302. doi:10.1051/ocl/2015012

Friedland, W.H., 1984. Commodity systems analysis: an approach to the sociology of agriculture, in: Schwarzweller, H.K. (Ed.), Research in Rural Sociology and Development. JAI Press, London, pp. 221-235.

FWRA, 2014. Analysis of U.S. Food Waste Among Food Manufacturers, Retailers, and Restaurants. Food Waste Reduction Alliance. Washington, DC.

Garcia-Garcia, G., Woolley, E., Rahimifard, S., 2015. A Framework for a More Efficient Approach to Food Waste Management. Int. J. Food Eng. 1 (1), 65-72. doi:10.18178/ijfe.1.1.65-72

Gentil, E.C., Gallo, D., Christensen, T.H., 2011. Environmental evaluation of municipal waste prevention. Waste Manag. 31, 2371-2379. doi:10.1016/j.wasman.2011.07.030

Gereffi, G., Humphrey, J., Sturgeon, T., 2005. The governance of global value chains. Rev. Int. Polit. Econ. 12 (1), 78-104. doi:10.1080/09692290500049805

Gereffi, G., Korzeniewicz, M., 1994. Commodity Chains and Global Capitalism, Contributions in economics and economic history. ABC-CLIO, Santa Barbara, CA.

Gunders, D., 2012. Wasted: How America is Losing Up to $40 \%$ of Its Food From Farm to Fork to Landfill (NRDC Issue Paper No. iP:12-06-B). Natural Resources Defense Council, Washington, DC.

Gustavsson, J., Cederberg, C., Sonesson, U., van Otterdijk, R., Meybeck, A., 2011. Global Food Losses and Food Waste. UN Food and Agricultural Organization, Rome.

Hall, K.D., Guo, J., Dore, M., Chow, C.C., 2009. The Progressive Increase of Food Waste in America and Its Environmental Impact. PLoS ONE 4 (11), e7940. doi:10.1371/journal.pone.0007940

Hawkins, G., 2012. The Performativity of Food Packaging: Market Devices, Waste Crisis and Recycling. Sociol. Rev. 60 (S2), 66-83. doi:10.1111/1467-954X.12038

HLPE, 2014. Food losses and waste in the context of sustainable food systems (No. 8), HLPE Report Series. High Level Panel of Experts on Food Security and Nutrition of the Committee on World Food Security, Rome.

H.R.4719: America Gives More Act of 2014, 2014. $113^{\text {th }}$ Congress. Available at: https://www.congress.gov/bill/113th-congress/house-bill/4719 (Accessed: 01/07/2016)

Hultman, J., Corvellec, H., 2012. The European Waste Hierarchy: From the Sociomateriality of Waste to a Politics of Consumption. Environ. Plan. A 44 (10), 2413-2427. doi:10.1068/a44668

Kantor, L.S., Lipton, K., Manchester, A., Oliveira, V., 1997. Estimating and Addressing America's Food Losses. U.S. Department of Agriculture, Washington, DC. 
Kummu, M., de Moel, H., Porkka, M., Siebert, S., Varis, O., Ward, P.J., 2012. Lost Food, Wasted Resources: Global Food Supply Chain Losses and Their Impacts on Freshwater, Cropland, and Fertiliser Use. Sci. Total Environ. 438, 477-489. doi:10.1016/j.scitotenv.2012.08.092

Laurent, A., Bakas, I., Clavreul, J., Bernstad, A., Niero, M., Gentil, E., Hauschild, M.Z., Christensen, T.H., 2014. Review of LCA studies of solid waste management systems-part I: lessons learned and perspectives. Waste Manag. 34, 573-588. doi:10.1016/j.wasman.2013.10.045

Le Borgne, G., Sirieix, L., 2013. Promotional offers, food wastage and skepticism: Literature review and proposal for a framework (Offres promotionnelles, gaspillage alimentaire et scepticisme: une revue de littérature et proposition d'un cadre d'analyse). Working Papers - UMR MOISA. INRA, Montpellier.

Leib, E.B., Gunders, D., 2013. The Dating Game. Natural Resources Defense Council, New York, NY.

Lorek, S., Fuchs, D., 2013. Strong sustainable consumption governance - precondition for a degrowth path? J. Clean. Prod. 38, 36-43. doi:10.1016/j.jclepro.2011.08.008

Lorek, S., Spangenberg, J.H., 2014. Sustainable consumption within a sustainable economy beyond green growth and green economies. J. Clean. Prod. 63, 33-44. doi:10.1016/j.jclepro.2013.08.045

Lundie, S., Peters, G.M., 2005. Life Cycle Assessment of Food Waste Management Options. J. Clean. Prod., Environmental Assessments and Waste Management 13 (3), 275-286. doi: 10.1016/j.jclepro.2004.02.020

Lundqvist, J., De Fraiture, C., Molden, D., 2008. Saving Water: From Field to Fork - Curbing Losses and Wastage in the Food Chain. (SIWI Policy brief). Stockholm International Water Institute, Stockholm.

Lyndhurst, B., 2011. Consumer Insight: Date Labels and Storage Guidance. Waste \& Resources Action Program, Banbury.

MAAF, 2013. National Pact to Fight Against Food Waste (Pacte national de lutte contre le gaspillage alimentaire). Ministry of Agriculture, Food and Forest, Paris.

MEDDE, 2012. Reducing Food Waste: Baseline Study and Plan for Action (Réduction du gaspillage alimentaire : État des lieux et pistes d'action). Ministry of Ecology, Sustainable Development and Energy, Paris.

Midgley, J.L., 2013. The Logics of Surplus Food Redistribution. J. Environ. Plan. Manag. 57 (12), 1872-1892. doi:10.1080/09640568.2013.848192

Mourad, M., 2015. France Moves Toward a National Policy Against Food Waste (No. R-1508-B). National Resources and Defense Council, New York, NY. Available at: http://www.nrdc.org/food/france-food-waste-policy.asp (Accessed: 10/6/2015)

Neff, R.A., Kanter, R., Vandevijvere, S., 2015a. Reducing Food Loss And Waste While Improving The Public's Health. Health Aff. 34 (11), 1821-1829. doi:10.1377/hlthaff.2015.0647

Neff, R.A., Spiker, M.L., Truant, P.L., 2015b. Wasted Food: U.S. Consumers’ Reported Awareness, Attitudes, and Behaviors. PLoS ONE 10 (6), e0127881. doi:10.1371/journal.pone.0127881 
O’Donnell, T.H., Deutsch, J., Yungmann, C., Zeitz, A., Katz, S.H., 2015. New Sustainable Market Opportunities for Surplus Food: A Food System-Sensitive Methodology (FSSM). Food Nutr. Sci. 6 (10), 883-892. doi:10.4236/fns.2015.610093

O’Rourke, D., Lollo, N., 2015. Transforming Consumption: From Decoupling, to Behavior, to Systems Change for Sustainable Consumption. Annu. Rev. Environ. Resour. 40 (1), 233-259. doi:10.1146/annurev-environ-102014-021224

Papargyropoulou, E., Lozano, R., K. Steinberger, J., Wright, N., Ujang, Z. bin, 2014. The food waste hierarchy as a framework for the management of food surplus and food waste. J. Clean. Prod. 76, 106-115. doi:10.1016/j.jclepro.2014.04.020

Perc, M., Gómez-Gardeñes, J., Szolnoki, A., Floría, L.M., Moreno, Y., 2013. Evolutionary dynamics of group interactions on structured populations: a review. J. R. Soc. Interface 10 (80). doi:10.1098/rsif.2012.0997

Perc, M., Szolnoki, A., 2010. Coevolutionary games--A mini review. Biosystems 99 (2), 109125. doi:10.1016/j.biosystems.2009.10.003

Phillips, C., Hoenigman, R., Higbee, B., Reed, T., 2011. Understanding the Sustainability of Retail Food Recovery. PLoS ONE 8 (10), e 75530. doi:10.1371/journal.pone.0075530

H.R.4184: Food Recovery Act of $2015,2015.114^{\text {th }}$ Congress. Available at: https://www.congress.gov/bill/114th-congress/house-bill/4184 (Accessed: 01/08/2016)

PIPAME, 2014. Technological innovations as drivers of waste reduction in the agro-food sector: challenges for consumers and enterprises (Les innovations technologiques, leviers de réduction du gaspillage dans le secteur agroalimentaire : enjeux pour les consommateurs et pour les entreprises), Prospective economic studies. Interministry Pole of Prospective and Forecast of Economic Mutations (Pôle interministériel de prospective et d'anticipation des mutations économiques), Paris.

Poppendieck, J., 1999. Sweet Charity? Emergency Food and the End of Entitlement. Penguin, New York

Reynolds, C.J., Piantadosi, J., Boland, J., 2015. Rescuing Food from the Organics Waste Stream to Feed the Food Insecure: An Economic and Environmental Assessment of Australian Food Rescue Operations Using Environmentally Extended Waste InputOutput Analysis. Sustainability 7 (4), 4707-4726. doi:10.3390/su7044707

Rothenberg, S., 2007. Environmental managers as institutional entrepreneurs: The influence of institutional and technical pressures on waste management. J. Bus. Res. 60 (7), 749-757. doi:10.1016/j.jbusres.2007.02.017

Samuel, H., 2015. France passes "pioneering” food waste bill to ban supermarkets from binning unused food. The Telegraph. Available at: http://www.telegraph.co.uk/news/worldnews/europe/france/12044568/France-passespioneering-food-waste-bill-to-ban-supermarkets-from-binning-unused-food.html (Accessed: 12/18/2015)

Schenck, R., Huizenga, D. (Eds.), 2014. Proceedings of the 9th International Conference on Life Cycle Assessment in the Agri-Food Sector (LCA Food 2014). Presented the LCA Food 2014, ACLCA, San Francisco, CA.

Schneider, F., 2013a. Review of food waste prevention on an international level. Waste Resour. Manag. - Proc. Inst. Civ. Eng. 166 (4), 187-203. doi:10.1680/warm.13.00016 
Schneider, F., 2013b. The evolution of food donation with respect to waste prevention. Waste Manag., Special Thematic Issue: Urban Mining 33 (3), 755-763. doi:10.1016/j.wasman.2012.10.025

Schurman, R., Munro, W.A., 2010. Fighting for the Future of Food: Activists versus Agribusiness in the Struggle over Biotechnology. University of Minnesota Press, Minneapolis, $\mathrm{MN}$.

Snow, D., Benford, R., 1992. Master Frames and Cycles of Protest, in: Morris, A.D., Mueller, C.M. (Eds.), Frontiers in Social Movement Theory. Yale University Press, New Haven, CT, pp. 133-155.

Stuart, T., 2009. Waste: Uncovering the Global Food Scandal. W. W. Norton \& Company, New York.

Thyberg, K.L., Tonjes, D.J., 2016. Drivers of food waste and their implications for sustainable policy development. Resour. Conserv. Recycl. 106 (January 2016), 110 123. doi:10.1016/j.resconrec.2015.11.016

Tukker, A., Vezzoli, C., Stø, E., Charter, M., Andersen, M. (Eds.), 2008. System Innovation for Sustainability: Perspectives on Radical Changes to Sustainable Consumption and Production. Greenleaf, Sheffield.

US EPA, 2011. The Food Recovery Hierarchy. Resources Conservation - Food Waste. Available at: http://www.epa.gov/foodrecovery/ (Accessed: 5/12/15).

Van Ewijk, S., Stegemann, J.A., 2015. Limitations of the waste hierarchy for achieving absolute reductions in material throughput. J. Clean. Prod. (in press), 1-7. doi:10.1016/j.jclepro.2014.11.051

Venkat, K., 2011. The Climate Change and Economic Impacts of Food Waste in the United States. Int. J. Food Syst. Dyn. 2 (4), 431-446. doi:http://dx.doi.org/10.18461/ijfsd.v2i4.247

Vittuari, M., Politano, A., Gaiani, S., Canali, M., Elander, M., 2015. Review of EU Legislation and Policies with Implications on Food Waste. FUSIONS, Bologna.

Williams, H., Wikström, F., 2011. Environmental impact of packaging and food losses in a life cycle perspective: a comparative analysis of five food items. J. Clean. Prod. 19, 43-48. doi:10.1016/j.jclepro.2010.08.008

Willis, M.M., Schor, J.B., 2012. Does Changing a Light Bulb Lead to Changing the World? Political Action and the Conscious Consumer. Ann. Am. Acad. Pol. Soc. Sci. 644 (1), 160-190. doi:10.1177/0002716212454831

WRAP, 2013. Household food and drink waste in the UK 2012. Waste \& Resources Action Program, Banbury.

WRI, 2014. Food Loss \& Waste (FLW) Protocol. Available at: http://www.wri.org/sites/default/files/uploads/2014_FLW_Protocol_Overview_Dec.p df (Accessed: 5/12/2015)

Yepsen, R., 2015. Residential Food Waste Collection in the U.S. BioCycle 56 (1), 53-63.

Zorpas, A.A., Lasaridi, K., 2013. Measuring waste prevention. Waste Manag. 33, 1047-1056. doi:10.1016/j.wasman.2012.12.017 
Figures and annexes:

3 Fig. 1. Mobilization around food waste in the United States and France

\begin{tabular}{|c|c|c|c|c|}
\hline & Before 2009 & $2010-2011$ & $2012-2013$ & $2014-2015$ \\
\hline \multirow[t]{2}{*}{ Advocacy } & $\begin{array}{c}\text { Food Not Bombs (1987), } \\
\text { Freegans } \\
\text { Stuart's Waste }\end{array}$ & $\begin{array}{l}\text { Bloom's American } \\
\text { Wasteland }\end{array}$ & $\begin{array}{c}\text { Feeding the } 5000 \text { in Paris } \\
\text { Disco Soupe } \\
\text { NRDC's Wasted }\end{array}$ & $\begin{array}{l}\text { Feeding the } 5000 \\
\text { In Oakland (CA) }\end{array}$ \\
\hline & \multirow{3}{*}{$\begin{array}{l}\text { Zero Waste programs } \\
\text { and campaigns }\end{array}$} & \multirow{3}{*}{$\begin{array}{c}\text { EPA's Food Recovery } \\
\text { Challenge \& } \\
\text { Food: too good to waste }\end{array}$} & \multicolumn{2}{|c|}{ Zero Food Waste Forum } \\
\hline $\begin{array}{lr}\text { Environment } \\
\frac{0}{0} & \text { \& waste }\end{array}$ & & & $\begin{array}{c}\text { FAO's Food Wastage } \\
\text { Footprint }\end{array}$ & $\begin{array}{l}\text { 'Mandatory } \\
\text { composting' laws }\end{array}$ \\
\hline क. & & & French National Pact & U.S. National Goal \\
\hline $\begin{array}{rr}\frac{0}{2} & \text { Agriculture } \\
\frac{2}{2} & \text { \&food } \\
\frac{2}{2} & \end{array}$ & $\begin{array}{l}\text { USDA 'food availability' } \\
\qquad(1970 \text { s })\end{array}$ & $\begin{array}{l}\text { FAO's Food Losses and } \\
\text { Waste }\end{array}$ & $\begin{array}{l}\text { USDA-EPA's US Food } \\
\text { Waste Challenge }\end{array}$ & $\begin{array}{l}\text { French 'national policy } \\
\text { to fight food waste' }\end{array}$ \\
\hline $\begin{array}{l}\text { Industry, retail } \\
\& \text { catering }\end{array}$ & & $\begin{array}{c}\text { Food Waste Reduction } \\
\text { Alliance }\end{array}$ & $\begin{array}{c}\text { 'Food waste' in CSR reports } \\
\text { French Start-up Zéro } \\
\text { Gâchis }\end{array}$ & $\begin{array}{l}\text { Intermarche's 'Ugly } \\
\text { fruit' campaign }\end{array}$ \\
\hline $\begin{array}{l}\text { Start-ups \& } \\
\text { NGOs }\end{array}$ & $\begin{array}{l}\text { Food banks (1980s) } \\
\text { Good Samaritan Act } \\
\text { (1996) }\end{array}$ & $\begin{array}{c}\text { France's Gleaning Tent } \\
\text { US's Food Recovery } \\
\text { Network }\end{array}$ & \multicolumn{2}{|c|}{$\begin{array}{l}\text { Online platforms for businesses (Phénix, Zero } \\
\text { Percent...), farmers (Cropmobster) \& consumers } \\
\text { (Partage ton Frigo, Falling Fruit...) }\end{array}$} \\
\hline
\end{tabular}

(Graph: Marie Mourad)

$7 \quad$ Fig. 2. Competing hierarchies of solutions to surplus food

\section{Hierarchies:}

\section{Solutions:}
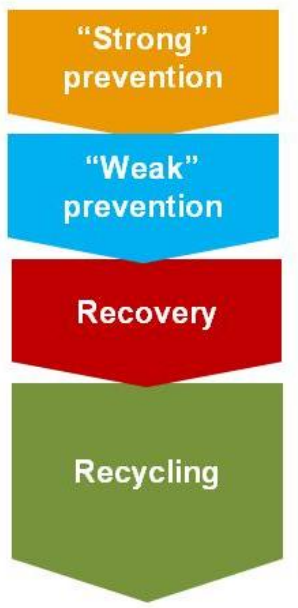

Legend:

Most promoted

(Graph: Marie Mourad)

\section{Environmental}

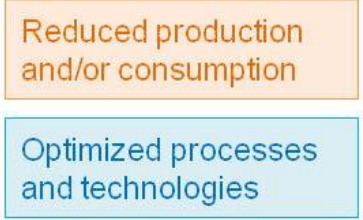

Re-use for human consumption

Re-use for animal feed and industry

Composting and waste-to-energy

Landfill
Economic

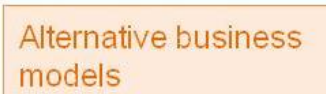

Optimization, lower costs and more sales

Tax and image benefits

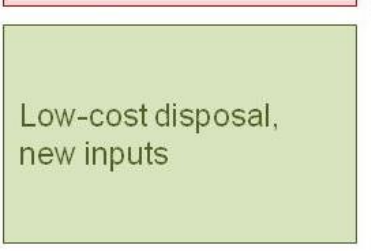

Disposal fees
Social

Food sovereignty, access to quality food

Access to low-cost products

Food banking, access to extra food

Inadequate or insufficientfood 
2 Fig. 3. Potential benefits and limitations of each category of solutions

\begin{tabular}{|c|c|c|c|c|}
\hline Solutions & Concrete examples & Key proponents & Benefits & Obstacles and limitations \\
\hline $\begin{array}{l}\text { "Strong" } \\
\text { prevention }\end{array}$ & $\begin{array}{l}\text { Direct and local exchanges, } \\
\text { shared / free food, seasonal } \\
\text { consumption, reduced meat } \\
\text { consumption }\end{array}$ & $\begin{array}{l}\text { Radical social } \\
\text { movements, small- } \\
\text { scale farmers }\end{array}$ & $\begin{array}{l}\text { Long-term } \\
\text { environmental } \\
\text { sustainability, food } \\
\text { sovereignty }\end{array}$ & $\begin{array}{l}\text { Vested interests of influential } \\
\text { actors in the current system } \\
\text { (large-scale agri-businesses, } \\
\text { retailers, waste management), } \\
\text { consumer resistance to change }\end{array}$ \\
\hline $\begin{array}{l}\text { "Weak" } \\
\text { prevention }\end{array}$ & $\begin{array}{l}\text { Optimized production and } \\
\text { stock management processes, } \\
\text { discount shelves, smart } \\
\text { labelling, consumer } \\
\text { awareness }\end{array}$ & $\begin{array}{l}\text { Large-scale agri- } \\
\text { businesses, retailers }\end{array}$ & $\begin{array}{l}\text { Direct economic } \\
\text { benefits for companies } \\
\text { (lower costs, more } \\
\text { sales) }\end{array}$ & $\begin{array}{l}\text { Many processes already } \\
\text { optimized, generally resource- } \\
\text { intensive technologies (e.g. } \\
\text { packaging, apps, GMOs) }\end{array}$ \\
\hline Recovery & $\begin{array}{l}\text { Food donations and } \\
\text { redistribution, smartphone } \\
\text { apps to connect donors and } \\
\text { non-profits }\end{array}$ & $\begin{array}{l}\text { Large-scale } \\
\text { manufacturers, } \\
\text { retailers, food } \\
\text { assistance networks, } \\
\text { social enterprises }\end{array}$ & $\begin{array}{l}\text { Short-term social } \\
\text { benefits (hunger-relief), } \\
\text { reputation and tax } \\
\text { benefits for companies }\end{array}$ & $\begin{array}{l}\text { Logistical constraints, } \\
\text { insufficient remedy for food } \\
\text { insecurity in the long term (low } \\
\text { quality, undignified and } \\
\text { irregular access) }\end{array}$ \\
\hline Recycling & $\begin{array}{l}\text { Separate collection of food } \\
\text { wastes, animal feed, } \\
\text { anaerobic digestion facilities, } \\
\text { on-site composting }\end{array}$ & $\begin{array}{l}\text { Large-scale agri- } \\
\text { businesses, food } \\
\text { service, waste } \\
\text { management }\end{array}$ & $\begin{array}{l}\text { Savings on landfill } \\
\text { costs, direct and } \\
\text { measurable } \\
\text { environmental benefits }\end{array}$ & $\begin{array}{l}\text { Large financial investment for } \\
\text { infrastructure, unstable end } \\
\text { markets, perverse incentives } \\
\text { (need for materials, reduced } \\
\text { donation and prevention efforts) }\end{array}$ \\
\hline
\end{tabular}

(Graph: Marie Mourad)

5 Fig. 4. Key developments around food surplus and waste in the United States and France

\begin{tabular}{|l|l|}
\hline Solutions & France \\
\hline $\begin{array}{l}\text { National } \\
\text { strategies }\end{array}$ & $\begin{array}{l}\text { National Pact (2012-2013) } \\
50 \% \text { Reduction goal promoted by } \\
\text { the national government (2013) } \\
\text { Marginal development of direct } \\
\text { sales (<3\% sales); no major } \\
\text { change in the CAP } \\
\text { "Strong" } \\
\text { prevention }\end{array}$ \\
\hline $\begin{array}{l}\text { Supermarket "ugly fruit" campaign? } \\
\text { "Weak" }\end{array}$ & $\begin{array}{l}\text { "Zero-waste" apps } \\
\text { prevention }\end{array}$ \\
\hline Recovery & $\begin{array}{l}\text { Tax reduction: } 60 \% \text { of donation } \\
\text { (based on stock value) }\end{array}$ \\
\hline $\begin{array}{l}\text { Mandatory donation bill (partly } \\
\text { voted) }\end{array}$ \\
\hline $\begin{array}{l}\text { EU 2008 directive } \\
\text { Mandatory recycling of organic } \\
\text { waste above 10t per year }\end{array}$ \\
\hline Recycling & $\begin{array}{l}\text { High subsidies for infrastructures } \\
\text { (Graph: Marie Mourad) }\end{array}$ \\
\hline
\end{tabular}

\section{United States}

Zero Food Waste Forum (2014)

$50 \%$ Reduction goal promoted by

USDA and EPA (2015)

Marginal development of direct sales $(0.3 \%$ of sales); no major change in the Farm Bill

"Zero-waste" apps

Smart packaging, GMOs?

Tax deduction: $15 \%$ of donation (based on market value, with additional credits in 7 states)

Good Samaritan Law (1996) Large food banks network

\section{EPA guidelines}

Mandatory composting in

California, commercial food waste disposal ban in Massachusetts

Private, on-site recycling

\section{Comparative development}

Longer multi-stakeholder mobilization in France that encourages food waste reduction

Very marginal alternatives to food systems in both places: food waste concerns not yet included in agricultural policies

More technical-oriented innovation in the U.S.

Stronger awareness and stores' engagement in France

More proactive regulations in France

Stronger culture of charity in the U.S.

Stricter thresholds for organic recycling in France, but very proactive regulations in some U.S. states (e.g. California)

Food waste increasingly commoditized in both places. 


\begin{tabular}{|c|c|c|c|c|c|c|}
\hline \multirow[b]{2}{*}{ CATEGORIES } & \multicolumn{3}{|c|}{ FIELDWORK IN FRANCE } & \multicolumn{3}{|c|}{ FIELDWORK IN THE U.S. } \\
\hline & $\underset{\text { interviews }}{\text { Primary }}$ & $\begin{array}{l}\text { Secondary } \\
\text { interviews }\end{array}$ & Observations & $\begin{array}{c}\text { Primary } \\
\text { interviews }\end{array}$ & $\begin{array}{l}\text { Secondary } \\
\text { interviews }\end{array}$ & Observations \\
\hline $\begin{array}{l}\text { Start-ups and non- } \\
\text { profits focused on food } \\
\text { waste (prevention and } \\
\text { recovery) }\end{array}$ & 15 & 0 & $\begin{array}{l}5 \text { events and conferences on } \\
\text { innovation and gleaning } \\
\text { projects, } 24 \text { days with an } \\
\text { awareness movement }\end{array}$ & 12 & 11 & $\begin{array}{l}\text { Regular volunteer work for an } \\
\text { NGO focused on food waste } \\
\text { during } 8 \text { months }\end{array}$ \\
\hline $\begin{array}{c}\text { International } \\
\text { organizations and } \\
\text { public sector } \\
\text { (national and local } \\
\text { levels) }\end{array}$ & 15 & 5 & $\begin{array}{c}4 \text { conferences, regular } \\
\text { working groups for the } \\
\text { National Pact and } 2 \text { studies } \\
\text { on household food waste } \\
\text { (national agency) }\end{array}$ & 9 & 1 & - \\
\hline $\begin{array}{l}\text { Advocacy and activism } \\
\text { (NGOs, experts, } \\
\text { consumer organizations) }\end{array}$ & 10 & 6 & $\begin{array}{c}3 \text { conferences and events, } \\
\text { including the Zero Waste } \\
\text { movement }\end{array}$ & 6 & 9 & $\begin{array}{l}5 \text { events including the Zero } \\
\text { Food Waste Forum, } \\
\text { government agencies' } \\
\text { webinars, collaboration with } \\
\text { an environmental NGO }\end{array}$ \\
\hline $\begin{array}{c}\text { Wholesale and retail } \\
\text { (commodity markets, } \\
\text { distributors, grocery } \\
\text { stores) }\end{array}$ & 9 & 3 & $\begin{array}{c}5 \text { visits (stores, } \\
\text { warehouses), food pick-ups, } \\
\text { observation of dumpsters }\end{array}$ & 8 & 0 & $\begin{array}{l}2 \text { conferences and webinars } \\
\text { (industry groups), food pick- } \\
\text { ups, observation of dumpsters }\end{array}$ \\
\hline $\begin{array}{l}\text { Catering and } \\
\text { restaurants }\end{array}$ & 4 & 4 & - & 5 & 2 & $\begin{array}{l}1 \text { visit (university restaurant } \\
\text { kitchen) }\end{array}$ \\
\hline $\begin{array}{l}\text { Farming, processing } \\
\text { and packaging industry }\end{array}$ & 8 & 1 & $\begin{array}{c}2 \text { visits (farm, fruit picking), } \\
2 \text { conferences }\end{array}$ & 7 & 1 & $\begin{array}{l}3 \text { visits (farm and packing } \\
\text { facilities), industry webinar }\end{array}$ \\
\hline $\begin{array}{c}\text { Food assistance } \\
\text { organizations } \\
\text { (food banks, charities) }\end{array}$ & 4 & 0 & - & 6 & 4 & $\begin{array}{l}4 \text { visits (warehouses, soup } \\
\text { kitchens) }\end{array}$ \\
\hline Waste management & 3 & 0 & $\begin{array}{l}2 \text { visits (transfer station, } \\
\text { recycling and incineration } \\
\text { facility) }\end{array}$ & 4 & 1 & $\begin{array}{l}1 \text { conference, } 4 \text { visits (transfer } \\
\text { station, composting facility, } \\
\text { digester, landfill) }\end{array}$ \\
\hline TOTAL & 68 & 19 & & 57 & 29 & \\
\hline
\end{tabular}

3

$4 \quad$ Annex 2. Detailed fieldwork data

$5 \quad$ [see separate document] 